\section{Long term mechanical properties of self-compacting concrete made with slag cement and supplementary cementitious materials}

AbduLKader EL MIR - BME Department of Construction Materials and Technologies

- abdelkader.elmir@hotmail.com

Salem Georges NEHME - BME Department of Construction Materials and Technologies - sgnehme@yahoo.com

Érkezett: 2017. 04. 03. - Received: 03. 04. 2017. " https://doi.org/10.14382/epitoanyag-jsbcm.2017.11
Abdulkader EL MIR MSc Civil Engineer, PhD student at BME, Department of Construction Materials and Technologies. Fields of interest: porosity of concrete, self compacting concretes, high performance concretes.

Salem Georges NEHME MSc Civil Engineer, PhD, Associate Professor at BME, Department of Construction Materials and Technologies. Fields of interest: concrete technology, mass concrete, self-compacting concrete, fibre reinforced concrete, quality control of building materials, non-destructive testing, reinforced concrete structures, recycling of building materials.

\begin{abstract}
:
Self-compacting concrete (SCC) is becoming more popular in terms of application and innovation in the building industry. Durable concrete structures can be established when SCC is used with the proper mix design and selection of materials. The amount and type of filler or supplementary cementitious materilas (SCMs) are among the most important parameters affecting the fresh and hardened properties of SCC. Mainly, SCMs improve the hydration of cement due to their physical characteristics and chemical compositions, thus a more sustainable and eco-friendly SCC product could be achieved by the substitution of cement clinker by SCMs. The aim of this study was to evaluate the effect of total powder content, cement content and SCMs type on the fresh and hardened properties of SCC. The compressive strength, splitting tensile strength, modulus of elasticity and total porosity properties were the experimental tests carried out in this investigation. The finding of this study showed that the compressive strength of SCC with metakaolin (MK) gives higher values, as compared to mixtures with silica fume (SF), at the age of 400 days. MK and SF showed a negligible effect on the splitting tensile strength and modulus of elasticity, as compared to the reference mixtures. Total porosity test results were lower with the increase of total powder content and by the addition of SCMs.

Keywords: Self-compacting concrete, Mechanical properties, Sustainability, Metakaolin, Silica fume
\end{abstract}

\section{Introduction}

Concrete is a composite, time dependent material that is characterized by a complex pore structure. The latter affects the properties of concrete which can be controlled by the application of the proper combination of ingredients in the mix design. Pore size, shape and distribution highly affect the mechanical response of concrete such as the compressive strength, modulus of elasticity and other properties [1-3]. Self-compacting concrete (SCC) is a highly workable, nonsegregating concrete which is able to fill the formwork under its own weight and expand into the reinforcement without any mechanical intervention [4]. In general, SCC which falls into the high performance concrete category differs from normally vibrated concrete (NVC) with relatively higher paste content in order to achieve the desired rheological properties in the fresh stage [5]. Multiple fillers or supplementary cementitious materials (SCMs) with relatively different physical properties such as the particle size distribution and the specific surface area can be used to obtain the targeted paste in the design. Metakaolin (MK), silica fume (SF) and other SCMs are introduced into the concrete to enhance its performance and microstructure due to their physical and chemical effect on the hardened cement paste. Thereby, a more confined and less porous concrete network could be obtained [6-10]. Several studies had evaluated SCC characteristics in terms of the fresh and hardened properties. Today, the building industry main objective is towards applying more sustainable and eco-friendly materials. Hence the aim of this study was to evaluate the long term mechanical properties of SCC mixtures incorporating slag cement and SCMs.

The literature shared a lot of information regarding the compressive strength of concrete incorporating slag cement [11-13]. Shariq et al. [13] observed that concrete made with $40 \%$ replacement of the cement clinker by slag attained higher compressive strength as compared to the $20 \%$ and $60 \%$ replacement level of slag in concrete.

Most published articles acknowledged that for a selected compressive strength value, SCC could reach a tensile strength value which is slightly smaller than of NVC [14-18]. For instance, Parra et al. [14] registered lower values of splitting tensile strength of SCC made with limestone powder (LP) filler than that of NVC, however, Felekoglu et al. [17] showed that higher splitting tensile strength values were obtained in SCC rather than NVC.

Regarding the modulus of elasticity, SCC mixtures are considered to be more deformable as compared to NVC [17]. There are small differences in stiffness between SCC and NVC due to the high powder content in SCC, however, Su et al. [18] revealed that increasing the fine to total aggregate ratio did not have a major effect on SCC modulus of elasticity.

In almost all results available in the literature, SCC was mostly prepared with high amount of cement (higher than 
$400 \mathrm{~kg} / \mathrm{m}^{3}$ ) and other additives, filler or SCMs such as fly ash, slag and others. Therefore, the authors aimed to evaluate the performance of SCC with a selective range of the total powder and cement content.

\section{Experimental program}

\subsection{Materials}

Slag cement (C) CEM III/A 32.5 R, LP, MK, SF, natural Danube river sand $(0-4 \mathrm{~mm})$ and gravel $(4-8 \mathrm{~mm}, 8-16 \mathrm{~mm})$ were the used materials in this study. LP served as the filling material for SCC mixtures to ensure the desired rheological properties. MK and SF were the SCMs implemented to enrich the mechanical properties. A high range water reducing admixture (HRWRA) "Sika Viscocrete 5 Neu" was applied to serve the workability of SCC mixtures. Particle size distribution fractions of aggregates were: sand (0-4 mm, 45\%), small gravel (4-8 mm, 20\%) and medium gravel (8-16 $\mathrm{mm}, 35 \%)$. The physical properties and chemical compositions of the C, LP and SCMs are summarized in Table 1. Regarding the powder materials, the particle size distribution curves are shown in Fig. 1.

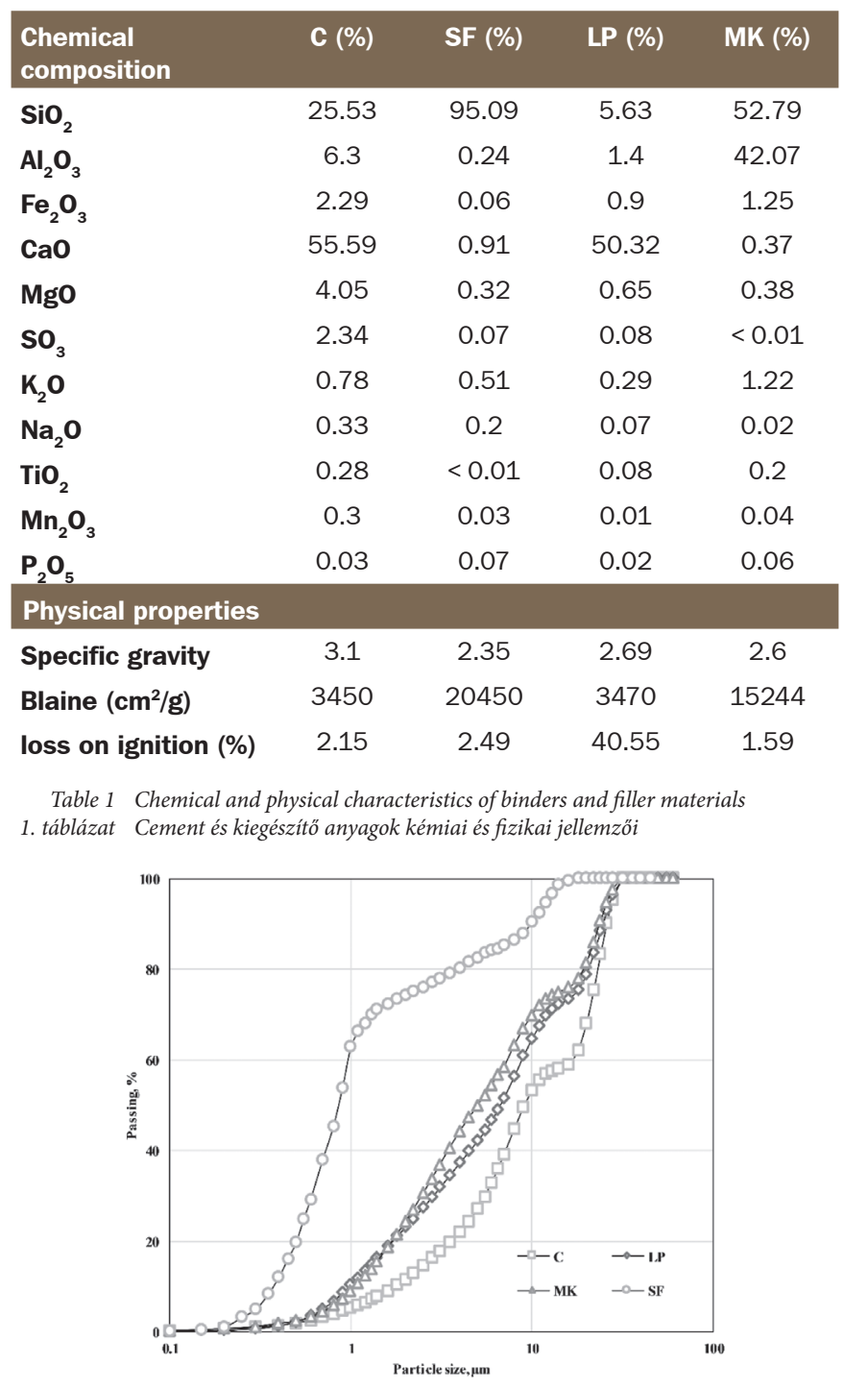

Fig. 1. Particle size distribution of powder materials

1. ábra Cement és kiegészitö anyagok szemcseméret eloszlása

\subsection{Mixtures proportion}

A total of twenty-seven SCC mixtures were planned in 3 main series: reference series (R), MK series (M) and SF series (S). Each of these series held 3 separate cement and total powder content $(320,360,400),(620,580,520)$ respectively. The total powder content is defined as the sum of cement, SCMs and LP used in this investigation. A constant amount of $40 \mathrm{~kg} / \mathrm{m}^{3}$ of $\mathrm{MK}$ or SF was added to the relevant $\mathrm{M}$ and $\mathrm{S}$ series independently. Also a constant amount of water was added for all SCC mixtures $\left(180 \mathrm{~kg} / \mathrm{m}^{3}\right)$. For more details, Table 2 shows the mixtures composition of all series. The mixing procedure started by mixing the aggregates, LP, cement and water together for one minute. MK or SF were added afterwards to the mixer with the required amount of HRWRA.

This selection of parameters contributed to the understanding of powder and binder effect on the mechanical response of SCC mixtures. Due to scope of the experiment, parameters related to the compressive strength and other mechanical properties were taken from a previous study [19].

$\begin{array}{lcccccc}\text { Mix ID } & \text { Cement } & \text { MK } & \text { SF } & \text { Total powder } & \text { Aggregates } & \text { HRWR } \\ \text { R1 } & 320 & 0 & 0 & 620 & 1520 & 3.04 \\ \text { R2 } & 360 & 0 & 0 & 620 & 1524 & 3.06 \\ \text { R3 } & 400 & 0 & 0 & 620 & 1529 & 3.56 \\ \text { R4 } & 320 & 0 & 0 & 580 & 1560 & 1.92 \\ \text { R5 } & 360 & 0 & 0 & 580 & 1565 & 2.02 \\ \text { R6 } & 400 & 0 & 0 & 580 & 1569 & 2.72 \\ \text { R7 } & 320 & 0 & 0 & 520 & 1618 & 1.74 \\ \text { R8 } & 360 & 0 & 0 & 520 & 1624 & 1.55 \\ \text { R9 } & 400 & 0 & 0 & 520 & 1629 & 1.76 \\ \text { M1 } & 320 & 40 & 0 & 620 & 1518 & 3.36 \\ \text { M2 } & 360 & 40 & 0 & 620 & 1524 & 3.96 \\ \text { M3 } & 400 & 40 & 0 & 620 & 1524 & 4.4 \\ \text { M4 } & 320 & 40 & 0 & 580 & 1557 & 2.72 \\ \text { M5 } & 360 & 40 & 0 & 580 & 1562 & 2.92 \\ \text { M6 } & 400 & 40 & 0 & 580 & 1564 & 4 \\ \text { M7 } & 320 & 40 & 0 & 520 & 1616 & 2.27 \\ \text { M8 } & 360 & 40 & 0 & 520 & 1620 & 2.34 \\ \text { M9 } & 400 & 40 & 0 & 520 & 1625 & 2.84 \\ \text { S1 } & 320 & 0 & 40 & 620 & 1506 & 5.44 \\ \text { S2 } & 360 & 0 & 40 & 620 & 1514 & 4.86 \\ \text { S3 } & 400 & 0 & 40 & 620 & 1520 & 5.2 \\ \text { S4 } & 320 & 0 & 40 & 580 & 1551 & 2.88 \\ \text { S5 } & 360 & 0 & 40 & 580 & 1556 & 3.17 \\ \text { S6 } & 400 & 0 & 40 & 580 & 1560 & 3.76 \\ \text { S7 } & 320 & 0 & 40 & 520 & 1611 & 2.31 \\ \text { S8 } & 360 & 0 & 40 & 520 & 1616 & 2.34 \\ \text { S9 } & 400 & 0 & 40 & 520 & 1620 & 2.72\end{array}$

Table 2. Mixtures composition for SCC mixtures series ( $R, M$ and $S$ ) 2. táblázat Vizsgált betonok összetétele ( $R, M$ és $S)$

\subsection{Fresh state evaluation}

In order to examine the adequacy of deformability and viscosity of the prepared SCC mixtures, slump flow and $\mathrm{V}$-funnel tests were carried out according to European 
Standards [20-21]. Also, refereeing to EFNARC guidelines for SCC [22], the aim of the evaluation was to obtain a slump flow criterion which belong to SF3 category. The latter could be achieved by the proper addition of HRWRA and selection of the maximum aggregate size of $16 \mathrm{~mm}$.

\section{4 Hardened state evaluation}

To characterize SCC mixtures in the hardened state, four types of tests were carried out: compressive strength, splitting tensile strength, modulus of elasticity and total porosity tests. As for the compressive strength test, $150 \mathrm{~mm}$ cubic specimens were tested at the age of 28 and 400 days in accordance with European standards [22]. However, the splitting tensile strength and modulus of elasticity were evaluated at the age of 400 days only [24-25]. The specimen dimensions were $150 \mathrm{~mm}$ cubes (splitting tensile strength) and $150 \times 300 \mathrm{~mm}$ cylinders (modulus of elasticity).

Total porosity in hardened concrete was calculated. It was determined based on the ratio of bulk (containing open and closed pores) and particle (containing no pores) densities of concrete specimens. Bulk density was measured referring to ASTM C642 standards [26]. Shredded specimens were crushed and grounded into fine powder reaching an average diameter size of $0.02 \mathrm{~mm}$ in order to evaluate true densities using the pycnometer [27]. Hence, the total porosity was obtained from the following equation:

$P_{T}=1-\frac{\rho_{b}}{\rho_{p}}$

$\rho_{b}$ and $\rho_{p}$ are the bulk and particle densities $\left(\mathrm{g} / \mathrm{cm}^{3}\right)$ respectively.

\section{Results and analysis}

\subsection{Rheological properties}

The amount of HRWRA varied between SCC series. In case of S1 mixture, the highest dosage of HRWRA $\left(5.44 \mathrm{~kg} / \mathrm{m}^{3}\right)$ was required. It appeared that with higher total powder content, more HRWRA amount is needed to ensure the workability of concrete. As it can be seen in Fig. 3, SCC mixtures with highest total powder content $\left(620 \mathrm{~kg} / \mathrm{m}^{3}\right)$ have a mean amount of HRWRA of $4.1 \mathrm{~kg} / \mathrm{m}^{3}$. This value decreases with the decrease of total powder content reaching 2.90 and $2.20 \mathrm{~kg} / \mathrm{m}^{3}$ in case of 580 and $520 \mathrm{~kg} / \mathrm{m}^{3}$ respectively. This behavior could be explained by the effect of powder on enhancing the plastic viscosity of the mixture, thus, requiring additional HRWRA to obtained the desired workability [28].

The same pattern can be noticed with the cement content variation. According to Fig. 4, SCC mixtures with a corresponding value of $400 \mathrm{~kg} / \mathrm{m}^{3}$ of cement, showed a mean dosage value of $3.44 \mathrm{~kg} / \mathrm{m}^{3}$ of HRWRA. However, SCC mixtures with lower cement content (320 or $360 \mathrm{~kg} / \mathrm{m}^{3}$ ) had lower mean values of HRWRA (2.85 and $\left.2.91 \mathrm{~kg} / \mathrm{m}^{3}\right)$ respectively. Furthermore, the effects of MK and SF on SCC mixtures were also noticeable as compared to their reference mixtures. $\mathrm{S}$ and $\mathrm{M}$ series required additional amount of HRWRA (up to $52 \%$ and $35 \%$ ) in accordance with $\mathrm{R}$ series. Due to the higher specific surface area of SF particles compared with MK and C, the corresponding dosage of HRWRA was higher. Hassan et al. confirmed such behaviour by acknowledging that the addition of MK required less amount of HRWRA than SF at the same level of cement substitution [29].

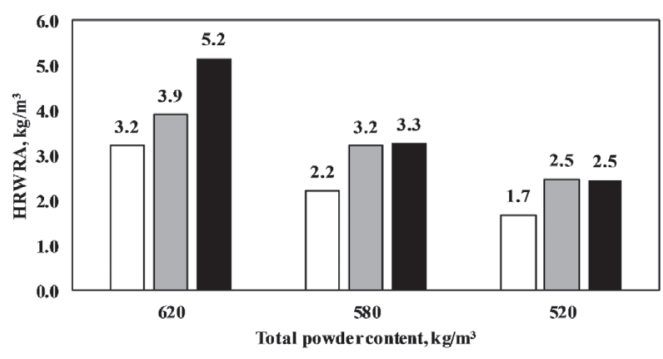

$\square \mathbf{R} \square \mathbf{M}=\mathbf{S}$

Fig. 3. Mean values of HRWRA dosages in terms of similar total powder content for SCC mixtures

3. ábra Folyósitószer adagolása azonos finomrész tartalmú SCC keverékekben

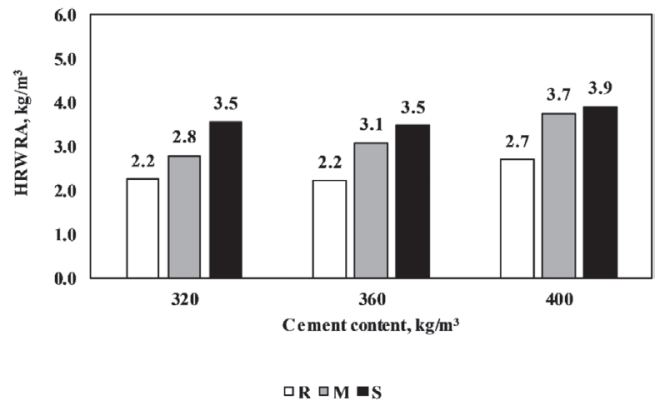

Fig. 4. Mean values of HRWRA dosages in terms of similar cement content for SCC mixtures 4. ábra Folyósitószer adagolása azonos cementtartalmú SCC keverékekben

\section{2 Compressive strength}

Absolute mean compressive strength values of SCC mixtures are summarized in Table 3. As it can be observed, SCC mixtures with $\mathrm{MK}$ or SF (M and S series) have higher compressive strength values than of those mixtures without SCMs (R series).

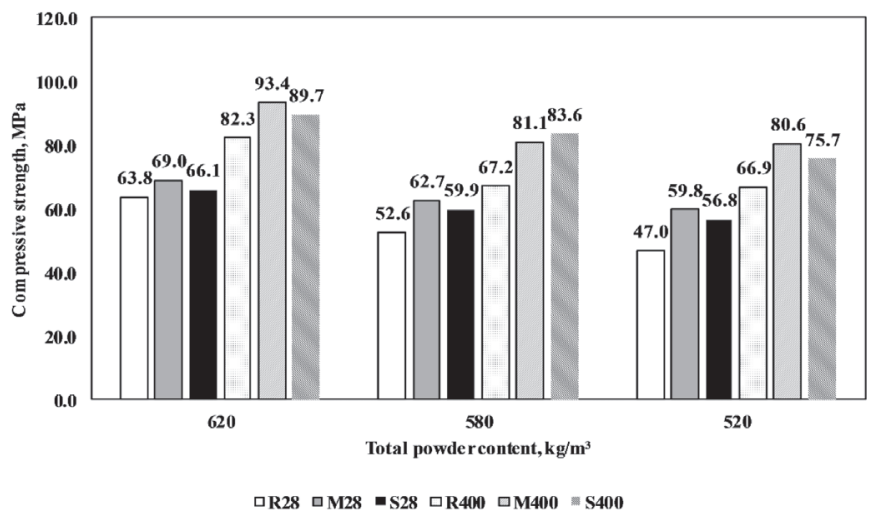

Fig. 5. Mean values of compressive strength in terms of similar total powder content for SCC mixtures at 28 and 400 days

5. ábra Megszilárdult beton nyomószilárdságának átlagos értéke 28 és 400 napos korban azonos finomrész tartalmú SCC keverékekre vonatkozóan

According to Fig. 5, The effect of total powder content and SCMs on the magnitude of the compressive strength is obvious. A decreasing tendency in the compressive strength is noticed with the decrease of the total powder content. SCC mixtures which possess the total powder content values of 580 and $520 \mathrm{~kg} / \mathrm{m}^{3}$ showed a mean decrease of the compressive strength of $13 \%$ and $21 \%$ at 28 days with respect to the highest total 
powder content $\left(620 \mathrm{~kg} / \mathrm{m}^{3}\right)$. Same pattern is noticed at 400 days of age with a mean decrease of $14 \%$ and $18 \%$ respectively. Therefore, the application of more LP filler considerably enhanced the strength of concrete once it was used along with SCMs (pozzolanic activity) [8]. To visualize the magnitude of SCMs, SCC mixtures were divided into three series. Maximum compressive strength values ( $77 \mathrm{MPa}$ at 28 days) was recorded for MK mixture (M3) which was considered to have the overall best performance. This behaviour would be explained by the high amount of total powder $\left(620 \mathrm{~kg} / \mathrm{m}^{3}\right)$ and binder content $\left(400 \mathrm{C}+40 \mathrm{MK} \mathrm{kg} / \mathrm{m}^{3}\right)$ as compared to other mixtures. In addition, S3 mixture which combines the same amount of powder and binder showed the second highest values of mean compressive strength as compared to M3 mixture.

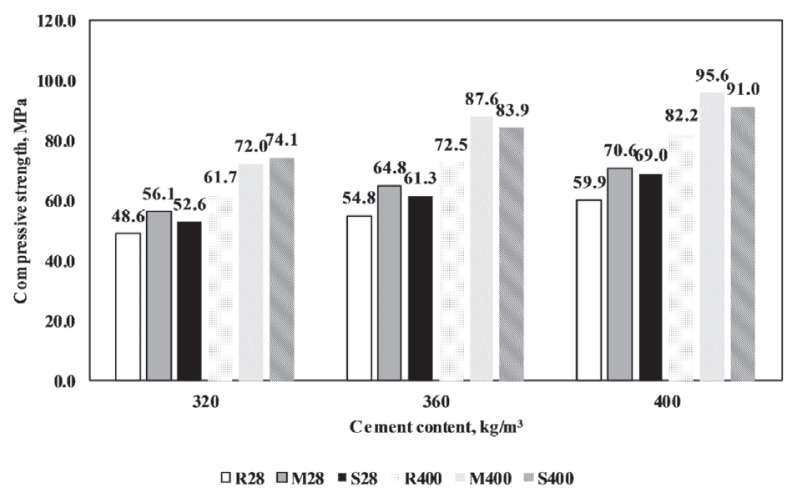

Fig. 6. Mean values of compressive strength in terms of similar cement content for SCC mixtures at 28 and 400 days

6. ábra Megszilárdult beton nyomószilárdságának átlagos értéke 28 és 400 napos korban azonos cementtartalmú SCC keverékekre vonatkozóan

Considering Fig. 6, the mean compressive strength values exhibited an increasing tendency with the increase of the cement content. In case of SCC mixtures that held a cement content of 400 $\mathrm{kg} / \mathrm{m}^{3}$, a mean increase of $26 \%$ was noticed with respect to SCC which held $320 \mathrm{~kg} / \mathrm{m}^{3}$ of cement. The same pattern was observed by $15 \%$ in case of SCC mixtures with $360 \mathrm{~kg} / \mathrm{m}^{3}$ of cement content. $\mathrm{M}$ and $\mathrm{S}$ series resulted in highest mean compressive strength values of 64 and $61 \mathrm{MPa}$ in comparision with $\mathrm{R}$ series of $54 \mathrm{MPa}$. The additional pozzolanic reaction (by converting $\mathrm{Ca}(\mathrm{OH})_{2}$ to extra calcium silicate hydrate in the accessible pore microstructure of the hardened cement paste) explains the MK and $\mathrm{SF}$ effect as compared to their reference mixtures. This is in agreement with the established fact in the literature $[30,31]$.

\subsection{Splitting tensile strength}

Splitting tensile strength of concrete is considered to indicate a primary mechanical characteristic that highly influences the size and extent of tension failure behaviour, such as flexural in beams and splitting which results from rebar friction interaction with the concrete [32]. Referring to Table 3, maximum splitting tensile strength was recorded to R3 mixture with $5.47 \mathrm{MPa}$. Looking at mixtures that correspond to $620 \mathrm{~kg} /$ $\mathrm{m}^{3}$ of total powder content, it could be seen that these mixtures showed the highest mean splitting tensile strength value (4.9 $\mathrm{MPa}$ ) in comparison with lower total powder content mixtures (580 and $520 \mathrm{~kg} / \mathrm{m}^{3}$ ) which have showed lower mean splitting tensile strength values (4.36 and 4.35 MPa) (Fig. 7).

\begin{tabular}{|c|c|c|c|c|c|}
\hline \multirow[t]{2}{*}{$\begin{array}{l}\text { Mixtures } \\
\text { ID }\end{array}$} & \multicolumn{2}{|c|}{$\begin{array}{l}\text { Compressive } \\
\text { strength } \\
\text { (MPa) }\end{array}$} & \multirow{2}{*}{$\begin{array}{l}\text { Splitting } \\
\text { Tensile } \\
\text { strength } \\
\text { (MPa) } \\
{ }^{*} \text { fspm,cube }\end{array}$} & \multirow{2}{*}{$\begin{array}{l}\text { Modulus } \\
\text { of } \\
\text { elasticity } \\
\text { (GPa) } \\
{ }^{* * *} \text { Ecm,cyl }\end{array}$} & \multirow{2}{*}{$\begin{array}{c}\text { Total } \\
\text { porosity } \\
\text { (V \%) } \\
\text { Pt }\end{array}$} \\
\hline & ${ }^{*}$ fcm, cube & fcm,cube & & & \\
\hline Days & 28 & 400 & 400 & 400 & 400 \\
\hline R1 & 57.90 & 71.68 & 4.68 & 30.94 & 12.78 \\
\hline $\mathbf{R} 2$ & 63.04 & 83.43 & 5.06 & 32.50 & 11.11 \\
\hline R3 & 70.39 & 91.83 & 5.47 & 37.85 & 9.06 \\
\hline R4 & 47.21 & 59.61 & 3.61 & 31.84 & 13.03 \\
\hline R5 & 52.76 & 65.66 & 4.21 & 33.44 & 12.07 \\
\hline R6 & 57.71 & 76.24 & 4.87 & 36.14 & 11.20 \\
\hline R7 & 40.72 & 53.74 & 3.31 & 25.81 & 14.84 \\
\hline R8 & 48.49 & 68.28 & 4.13 & 33.67 & 13.04 \\
\hline R9 & 51.66 & 78.67 & 4.51 & 33.55 & 10.85 \\
\hline M1 & 61.33 & 80.53 & 3.99 & 34.05 & 10.98 \\
\hline M2 & 68.80 & 94.88 & 4.66 & 37.92 & 11.54 \\
\hline M3 & 76.99 & 104.84 & 5.87 & 41.11 & 6.34 \\
\hline M4 & 56.11 & 70.53 & 3.78 & 31.96 & 12.50 \\
\hline M5 & 61.96 & 82.60 & 4.32 & 33.89 & 11.89 \\
\hline M6 & 69.90 & 90.22 & 5.12 & 33.27 & 8.98 \\
\hline M7 & 50.85 & 64.82 & 3.97 & 27.66 & 13.12 \\
\hline M8 & 63.61 & 85.44 & 4.44 & 29.64 & 10.23 \\
\hline M9 & 64.91 & 91.61 & 5.28 & 36.76 & 8.63 \\
\hline S1 & 59.00 & 77.44 & 4.16 & 31.79 & 7.59 \\
\hline S2 & 65.01 & 89.74 & 5.11 & 32.69 & 5.65 \\
\hline S3 & 74.43 & 101.87 & 5.20 & 37.70 & 5.15 \\
\hline S4 & 49.79 & 73.68 & 3.98 & 30.02 & 9.26 \\
\hline S5 & 59.41 & 85.55 & 4.25 & 33.36 & 8.86 \\
\hline 56 & 70.46 & 91.61 & 5.17 & 36.58 & 6.25 \\
\hline s7 & 48.91 & 71.16 & 4.04 & 29.91 & 12.48 \\
\hline S8 & 59.50 & 76.41 & 4.53 & 31.09 & 10.12 \\
\hline s9 & 61.98 & 79.53 & 4.94 & 35.39 & 8.16 \\
\hline
\end{tabular}

${ }^{*} f_{\text {cm,cube }}:$ mean compressive strength of tested cubic specimens;

$f_{c m, c u b e}:$ mean splitting tensile strength of tested cubic specimens;

${ }_{* * *} E_{c m, c y l}:$ mean modulus of elasticity of tested cylindrical specimens.

Table 3. Mechanical characteristics of the tested SCC mixtures 3. táblázat A vizsgált SCC keverékek mechanikai jellemzöi

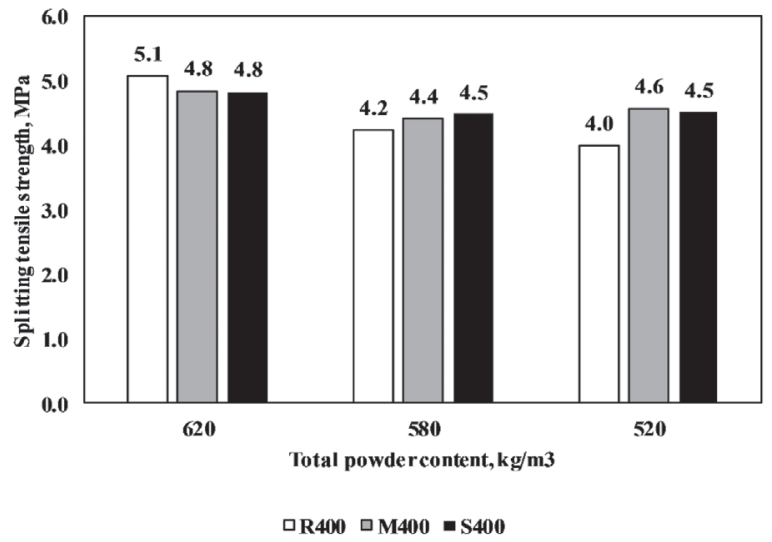

Fig. 7. Mean values of the splitting tensile strength in terms of similar total powder content for SCC mixtures at 400 days

7. ábra Megszilárdult beton hasitó-húzószilárdságának átlagos értéke 400 napos korban azonos finomrész tartalmú SCC keverékekre vonatkozóan 
Same pattern is observed in Fig. 8. With the increase of cement content, highest splitting tensile strength values are recorded in case of $400 \mathrm{~kg} / \mathrm{m}^{3}$ of cement. Therefore, it was obvious that the property of the splitting tensile strength for SCC mixtures is not too dependent on the disparities of the cement and total powder content parameters as it was in the compressive strength. This can be explained by the difference in mixtures combinations of materials, hence the variation in splitting tensile strength results may not give a clear relation with the variations in compressive strengths.

Generally, $\mathrm{M}$ and $\mathrm{S}$ series mixtures enhanced the splitting tensile strength by $4 \%$ with respect to $\mathrm{R}$ series. MK seemed to be slightly more effective in enhancing the splitting tensile strength of the mixture as compared to the SF mixtures.

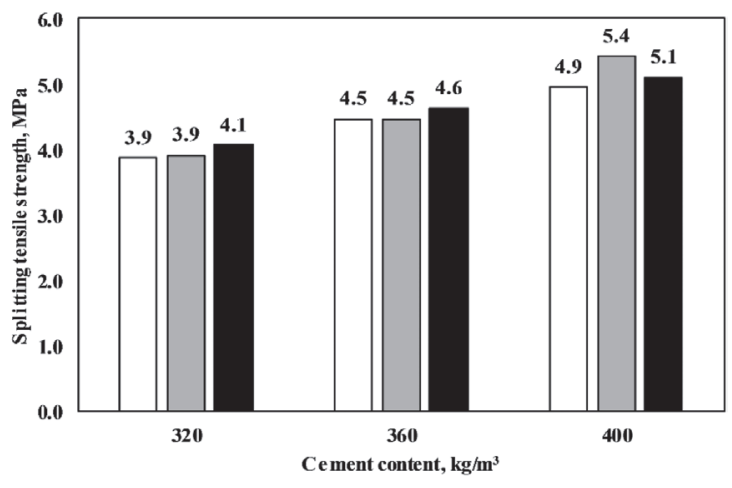

$\square R 400 \square M 400 \square S 400$

Fig. 8. Mean values of splitting tensile strength in terms of similar cement content for SCC mixtures at 400 days

8. ábra Megszilárdult beton hasitó-húzószilárdságának átlagos értéke 400 napos korban azonos cementtartalmú SCC keverékekre vonatkozóan

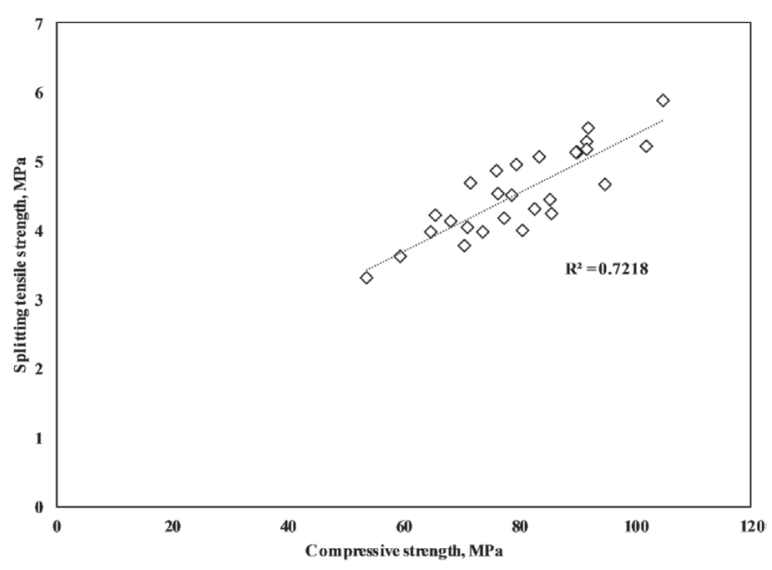

Fig. 9. Compressive and splitting tensile strength for SCC mixtures

9. ábra Vizsgált SCC keverékek nyomó- és hasitó-húzószilárdsága

The compressive and splitting tensile strength for SCC mixtures are correlated together and plotted in Fig. 9. A linear correlation with a good $\mathrm{R}^{2}$ value was found for $\mathrm{R}$ and $\mathrm{S}$ series. Thereby, it can be concluded that the splitting tensile strength of SCC directly relate to the compressive strength values.

\subsection{Modulus of elasticity}

Several concerns and interpretation have been reported regarding the behaviour of SCC towards the modulus of elasticity $[33,34]$. Thereby, this paper also covered the evaluation of the modulus of elasticity. Maximum values of the modulus of elasticity were recorded for M3 mixture with $41 \mathrm{GPa}$ (Table 3). Referring to Fig. 10, when mixtures with highest powder content $\left(620 \mathrm{~kg} / \mathrm{m}^{3}\right)$ were compared to the lower ones $\left(580\right.$ and $520 \mathrm{~kg} / \mathrm{m}^{3}$ ), the modulus of elasticity values that correspond to the highest showed the highest mean value $35.17 \mathrm{GPa}$ as compared to the others $\left(580\right.$ and $520 \mathrm{~kg} / \mathrm{m}^{3}$ ) which possess lower mean values of the modulus of elasticity (33.39 and $31.5 \mathrm{GPa})$.

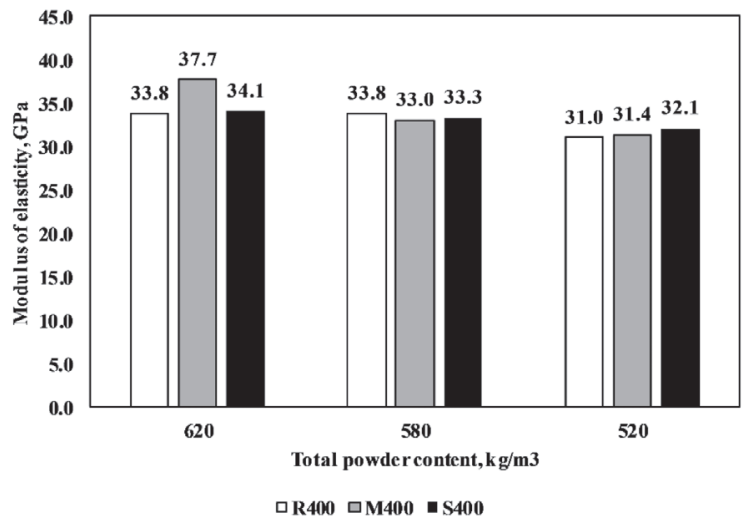

Fig. 10. Mean values of modulus of elasticity in terms of similar total powder conten for SCC mixtures at 400 days

10. ábra Megszilárdult beton rugalmassági modulusának átlagos értéke 400 napos korban azonos finomrész tartalmú SCC keverékekre vonatkozóan

Also, with the increase of the cement content, a positive effect on the modulus of elasticity results was achieved. As shown in Fig. 11, SCC mixtures with $400 \mathrm{~kg} / \mathrm{m}^{3}$ of cement content had higher mean value of modulus of elasticity as compared to 360 and $320 \mathrm{~kg} / \mathrm{m}^{3}$ respectively. The effect of MK and SF on enhancing the modulus of elasticity was shown to perform an negligible effect since the mean values of modulus of elasticity of $\mathrm{M}$ and $\mathrm{S}$ series are (34.03) and (33.17) GPa with respect to reference series $\mathrm{R}(32.86 \mathrm{GPa})$.

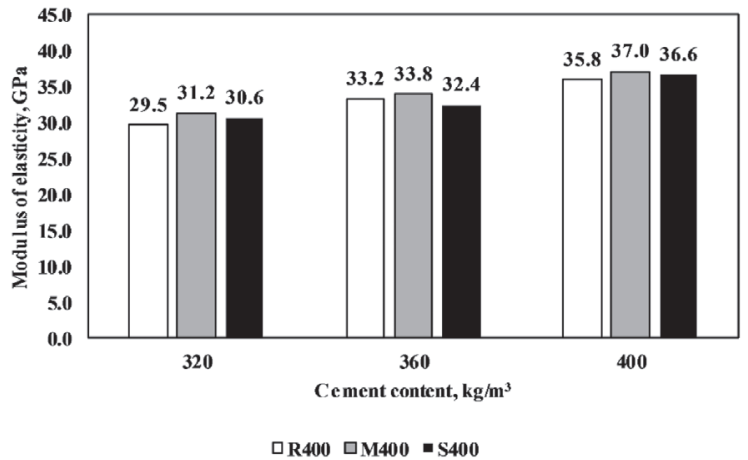

Fig. 11. Mean values of modulus of elasticity in terms of similar cement content of SCC mixtures at 400 days

11. ábra Megszilárdult beton rugalmassági modulusának átlagos értéke 400 napos korban azonos cementtartalmú SCC keverékekre vonatkozóan

Fig. 12 shows the relationship between the compressive strength and the modulus of elasticity of SCC series mixtures at the age of 400 days. The modulus of elasticity increases along with the compressive strength. Results showed acceptable correlation coefficient value $\left(R^{2}=0.607\right)$. 


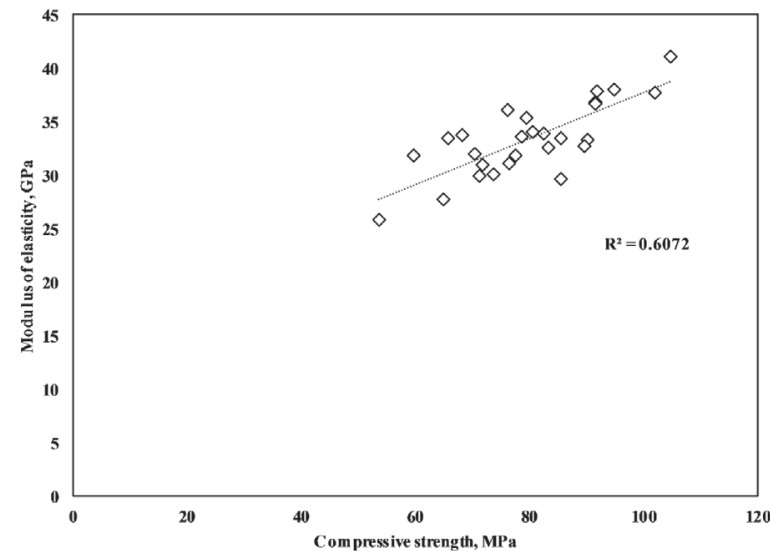

Fig. 12. Compressive strength and modulus of elasticity for SCC mixtures 12. ábra Vizsgált SCC keverékek nyomószilárdsága és rugalmassági modulusa

\subsection{Total porosity}

Absolute results of the mean values of the total porosity are presented in Table 3. R series held the highest total porosity mean value of $12 \%$, whereas lower values were shown for $\mathrm{M}$ and $\mathrm{S}$ series $(10.47 \%$ and $8.17 \%)$ respectively. Reference mixture R4 holds the maximum total porosity value of $13.19 \%$ which corresponds to the lowest cement content $\left(320 \mathrm{~kg} / \mathrm{m}^{3}\right)$. At the highest binder content $\left(400 \mathrm{C}+40 \mathrm{SF} \mathrm{kg} / \mathrm{m}^{3}\right)$, mixture S3 showed the lowest value of the total porosity (4.76\%).

Fig. 13 illustrates the mean values of total porosity of R, M and $\mathrm{S}$ series with respect to the total powder content.

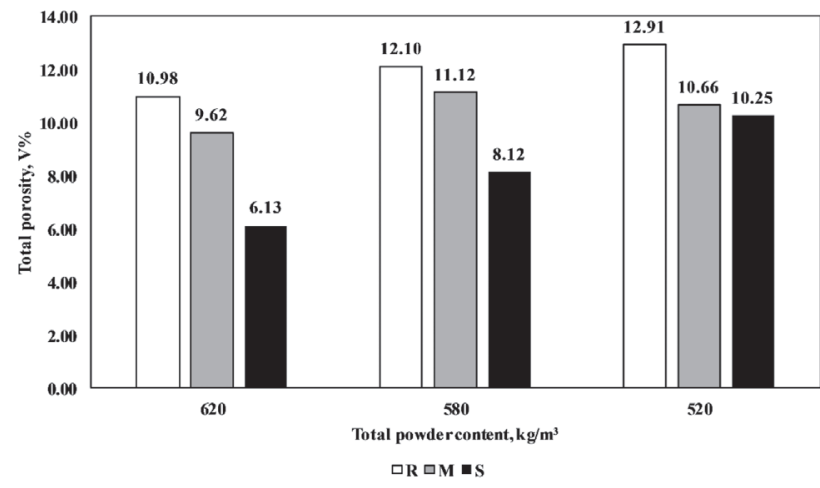

Fig. 13. Mean values of total porosity in terms of similar total powder content for SCC mixtures at 400 days

13. ábra Megszilárdult beton teljes porozitásának átlagos értéke 400 napos korban azonos finomrész tartalmú SCC keverékekre vonatkozóan

Generally, an increasing pattern is noticed for the total porosity along with the decrease of the total powder content. In case of the highest value of the total powder content $\left(620 \mathrm{~kg} / \mathrm{m}^{3}\right)$, the mean value of the total porosity is $8.91 \%$. When the total powder content decreases, the mean values of the total porosity increase (reaching $10.45 \%$ and $11.27 \%$ for 580 and $520 \mathrm{~kg} / \mathrm{m}^{3}$ respectively). Likewise, referring to Fig. 14, the same pattern was noticed when the cement content decreases. Regarding the effect of SCMs' on the total powder or cement content, MK and SF improved the total porosity in a mean value about $14 \%$ and $46 \%$ as compared to the reference series R. It was also proved by mercury intrusion porosimetry analysis that SCC with high powder content, the filling effect provided by the powder materials helped making the concrete porosity lower than NVC [35].

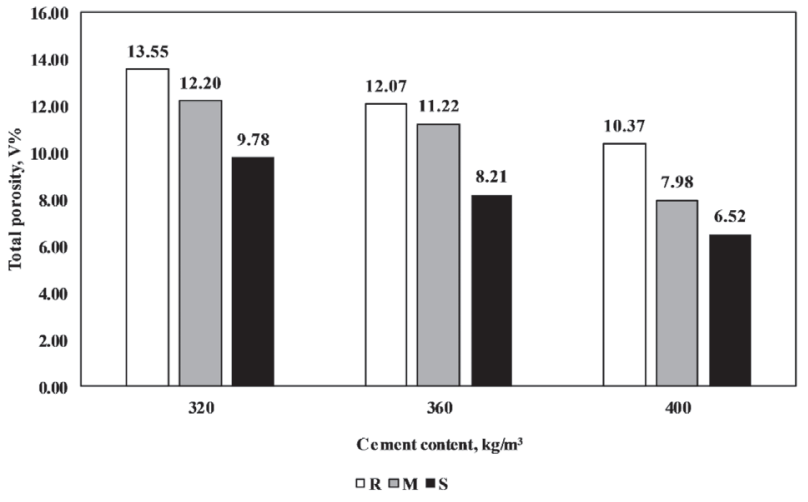

Fig. 14. Mean values of total porosity in terms of similar cement content for SCC mixtures at 400 days

14. ábra Megszilárdult beton teljes porozitásának átlagos értéke 400 napos korban azonos cementtartalmú SCC keverékekre vonatkozóan

Fig. 15 shows the linear correlation between the compressive strength and total porosity of SCC series mixtures at 400 days. A descending trend is observed when the total porosity and compressive strength values increase.

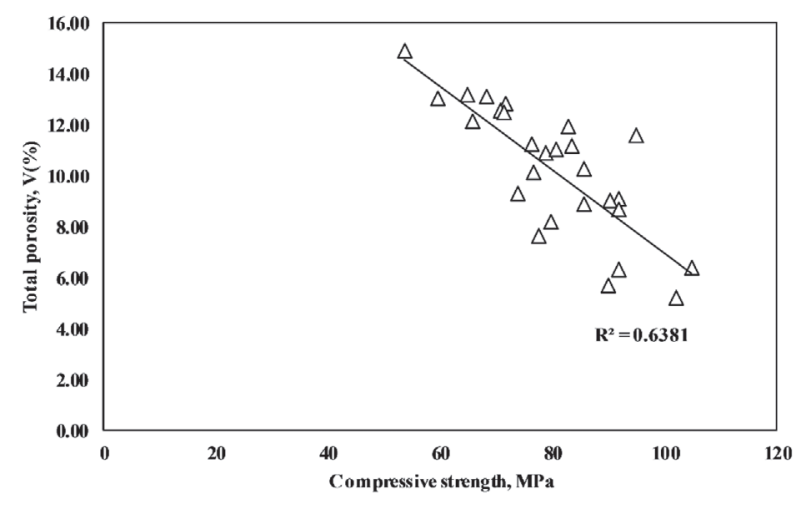

Fig.15. Compressive strength and total porosity for SCC mixture

15. ábra Vizsgált SCC keverékek nyomószilárdsága és teljes porozitása

\section{Conclusions}

As the SCC obliges a high amount of binders or additional filling materials for its production, the implementation of slag cement along with SCMs, is a good alternative leading to the reduction of clinker consumption. Based on the above study, the following conclusions can be drawn regarding the properties of the fresh and hardened SCC utilizing MK or SF as SCMs:

- HRWRA demand has increased along with the rise of the total powder content reaching up to $52 \%$ for S series as compared to the $\mathrm{R}$ series.

- The maximum compressive strength values were reported for the highest total powder content.

- The addition of MK as a SCM (M series) resulted in the highest values in terms of strength at the same level of addition $\left(40 \mathrm{~kg} / \mathrm{m}^{3}\right)$ as compared to SF (S series).

- As for the splitting tensile strength and modulus of elasticity tests, the experimental results showed that there is no correlation between them and the compressive strength.

- MK and SF had a negligible effect on enhancing the splitting tensile strength and the modulus of elasticity. 
- Total porosity results highly depend on the total powder and cement content.

- Total porosity was improved by the addition of SF and MK.

\section{Acknowledgment}

Authors would like to acknowledge the support of Sika Corp. and Lafarge for providing the necessary materials.

\section{References}

[1] Kondraivendhan. B. - Sabet Divsholi, B. - Teng, S. (2013): Estimation of strength, permeability and hydraulic diffusivity of pozzolana blended concrete through pore size distribution. Journal of Advanced Concrete Technology. Vol. 11, pp. 230-237, https://doi.org/10.3151/jact.11.230

[2] Patil, S. G. - Bhattacharjee, B. - ASCE, M. (2008): Size and volume relationship of pore for construction materials. Journal of Materials in Civil Engineering. Vol. 20, pp. 410-418.

https://doi.org/10.1061/(ASCE)0899-1561(2008)20:6(410)

[3] Barluenga, G. - Palomar, I. - Puentes, J. (2015): Hardened properties and microstructure of SCC with mineral additions. Construction and Building Materials. Vol. 94, pp. 728-736.

https://doi.org/10.1016/j.conbuildmat.2015.07.072

[4] Okamura, H. - Ouchi, M.: Self-compacting concrete. Development, present use and future. Kochi University of Technology, Japan, pp. 1-14.

[5] Okamura, H. - Ouchi, M. (2003): Self-Compacting Concrete. Journal of Advanced Concrete Technology. Vol. 1, pp. 5-15.

[6] Kavitha, O. R. - Shanthi, V. M. - Prince Arulraj, G. - Sivakumar, P. (2015): Fresh, micro- and macrolevel studies of metakaolin blended selfcompacting concrete. Applied Clay Science. Vol.114, pp. 370-374. https://doi.org/10.1016/j.clay.2015.06.024

[7] Borosnyói, A. (2016): Long term durability performance and mechanical properties of high performance concretes with combined use of supplementary cementing materials. Construction and Building Materials. Vol. 112, pp. 307-324. https://doi.org/10.1016/j.conbuildmat.2016.02.224

[8] Nehme, S. G. (2015): Kiegészítőanyagok hatása a szokványos és az öntömörödő betonokra (Influence of supplementary cementing materials on conventional and self-compacting concretes). Journal of Silicate Based and Composite Materials. Vol. 67, pp. 28-33. (In Hungarian) https://doi.org/10.14382/epitoanyag-jsbcm.2015.6

[9] Rashad, A. M. (2013): Metakaolin as cementitious material: History, scours, production and composition - A comprehensive overview. Construction and Building Materials. Vol. 41, pp. 303-318. https://doi.org/10.1016/j.conbuildmat.2012.12.001

[10] Siddique, R. (2011): Utilization of silica fume in concrete: Review of hardened properties. Resources, Conservation and Recycling. Vol. 55, pp. 923-932. 2011. https://doi.org/10.1016/j.resconrec.2011.06.012

[11] Li, Y. - Tian, P. (1997): Effect of slag and silica fume on mechanical properties of high strength concrete. Cement and Concrete Research. Vol. 27, pp. 833-837, 1997. https://doi.org/10.1016/S0008-8846(97)00076-8

[12] Olorunsogo, F. T. - Wainwright, P. J. (1998): Effect of GGBFS particlesized distribution on mortar compressive strength. Journal of Materials in Civil Engineering. Vol. 10, pp. 180-187.

[13] Shariq, M. - Prasad, J. - Masood, A. (2010): Effect of GGBFS on time dependent compressive strength of concrete. Construction and Building Materials. Vol. 24, pp. 1469-1478. https://doi.org/10.1016/j.conbuildmat.2010.01.007

[14] Parra, C. - Valcuenbe, M. - Gomez, F. (2011): Splitting tensile strength and modulus of elasticity of self-compacting concrete. Construction and Building Materials. Vol. 25, pp. 201-207. https://doi.org/10.1016/j.conbuildmat.2010.06.037

[15] Dehn, F. - Holschemacher, K. - Weiße, D. (2000): Self-Compacting Concrete (SCC) Time Development of the Material Properties and the Bond Behaviour. LACER. Vol. 5, pp. 115-124.

[16] Bosiljkov, V. B. (2003): SCC mixes with poorly graded aggregate and high volume of limestone filler. Cement and Concrete Research. Vol. 33, pp. 1279-1286. 2003. https://doi.org/10.1016/S0008-8846(03)00013-9

[17] Felekog 冈lu, B. - Türkel, S. - Baradan, B. (2007): Effect of water/cement ratio on the fresh and hardened properties of self-compacting concrete. Building and Environment. Vol. 42, pp. 1795-1802.

https://doi.org/10.1016/j.buildenv.2006.01.012

[18] Su, N. - Hsu, K. - Chai, H. (2001): A simple mix design method for selfcompacting concrete. Cement and Concrete Research. Vol. 31, pp. 17991807.

[19] El Mir, A. - Nehme, S. G. (2016): A comparative study on ultrasonic pulse velocity for normally vibrated and self-compacting concretes. Concrete Structures. Vol. 17, 8-12.

[20] BSI Standards Publication (2010): Testing fresh concrete Part 8: Selfcompacting concrete - Slump-flow test. British Standard Institution. BS EN 12350-8:2010.

[21] BSI Standards Publication (2010): Testing fresh concrete Part 9: Selfcompacting concrete - V-funnel test. British Standard Institution. BS EN 12350-9:2010.

[22] The European Guidelines for Self-Compacting Concrete. Specification, Production and Use. 2005.

[23] BSI Standards Publication (2013): Testing hardened concrete. Part 3: Compressive strength of test specimens. British Standard Institution. 2013. BS EN12390-3:2009.

[24] BSI Standards Publication (2013): Testing hardened concrete. 2013 Part 6: Tensile splitting strength of test specimens. British Standard Institution. BS EN12390-6:2009

[25] Hungarian Standards Publication (2013): Testing hardened concrete. Part 13: Determination of secant modulus of elasticity in compression. Magyar Szabványügyi Testület. MSZ EN 12390-13

[26] American Society of Testing Materials: 1997Standard Test Method for Density, Absorption, and Voids in Hardened Concrete. ASTM C 642.

[27] BSI Standards Publication (2014): Geotechnical investigation and testing - Laboratory testing of soil. Part 3: Determination of particle size density. ISO/DIS 17892-3

[28] Girish, S. - Ranganath, R. V. - Vengala, J. (2010): Influence of powder and paste on flow properties of SCC. Construction and Building Materials. Vol. 24, pp. 2481-2488. 2010. https://doi.org/10.1016/j.conbuildmat.2010.06.008

[29] Hassan, A. - Lachemi, M. - Hossain, K. (2012): Effect of metakaolin and silica fume on the durability of self-consolidating concrete. Cement \& Concrete Composites. Vol. 34, pp. 801-807.

https://doi.org/10.1016/j.cemconcomp.2012.02.013

[30] Güneyisi, E. - Gesoglu, M. - Karaoglu, S. - Mermerdas, K. (2012): Strength, permeability and shrinkage cracking of silica fume and metakaolin concretes. Construction and Building Materials. Vol. 34, pp. 120-130. https://doi.org/10.1016/j.conbuildmat.2012.02.017

[31] Adekunle, S. - Ahmad, S. - Maslehuddin, M. - Al-Gahtani, H. (2015): Properties of SCC prepared using natural pozzolana and industrial wastes as mineral fillers. Cement \& Concrete Composites. Vol. 62, pp. 125-133. 2015. https://doi.org/10.1016/j.cemconcomp.2015.06.001

[32] McCormac, J. C. - Brown, R. H. (2014): Design of Reinforced Concrete. Ninth Edition. Welter, J., Hong, S., Goldstein, S., John Wiley \& Sons, Inc., United States of America.

[33] Holschemacher, K. - Klug, Y. (2002): Database for the Evaluation of Hardened Properties of SCC. LACER. Vol.7, pp. 123-134.

[34] Leemann, A. - Hoffmann, C. (2005): Properties of self-compacting and conventional concrete - differences and similarities. Magazine of Concrete Research. Vol. 57, pp. 315-319.

[35] Liu, S. et al (2010): Effect of limestone powder on microstructure of concrete. Journal of Wuhan University of Technology-Mater. Sci. Ed. Vol.25, pp. 328-331. https://doi.org/10.1007/s11595-010-2328-5

$\underline{\text { Ref.: }}$

El Mir, Abdulkader - Nehme, Salem Georges: Long term mechanical properties of self-compacting concrete made with slag cement and supplementary cementitious materials

Építőanyag - Journal of Silicate Based and Composite Materials, Vol. 69, No. 2 (2017), 59-65. p. https://doi.org/10.14382/epitoanyag-jsbcm.2017.11 